\title{
A return to the nuclear waste dumping sites in the bays of Novaya Zemlya
}

\author{
S. Dahle ${ }^{1}$, V. Savinov ${ }^{1}$, J. Carroll ${ }^{1}$, M. Vladimirov ${ }^{2}$, G. Ivanov ${ }^{3}$, N. Valetova ${ }^{4}$, \\ Y. Gaziev", G. Dunaev, Z. Kirichenko ${ }^{4}$, A. Nikitin", G. Petrenko ${ }^{4}$, \\ A. Polukhina ${ }^{4}$, S. Kalmykov ${ }^{5}$, R. Aliev ${ }^{5}$ and M. Sabodina ${ }^{5}$ \\ ${ }^{1}$ Akvaplan-niva, Polar Environmental Center, 9296 Tromsø \\ ${ }^{2}$ Ministry of Emergency of the Russian Federation, 109012 Moscow, Russia \\ ${ }^{3}$ State Research and Production Company for Geological Sea Survey, \\ 198095 St-Petersburg, Russia \\ ${ }^{4}$ State Institution "Research and Production Association" (SI RPA) "Typhoon", \\ 249038 Obninsk, Russia \\ ${ }^{5}$ Radiochemistry Div., Chemistry Dept. of Lomonosov Moscow State University, \\ 119991 Moscow, Russia
}

\begin{abstract}
A new assessment of the nuclear dumping sites of Novaya Zemlya was performed in 2003/4. ${ }^{137} \mathrm{Cs}$ contamination levels within both Stepovogo and Abrosimova Bays are similar to background environmental levels and there has been no detectable leakage from objects in Tsivolki Bay. Near-surface sediment ${ }^{137} \mathrm{Cs}$ contamination levels in 2003/04 are 1-11 Bq/kg, 4-268 Bq/kg, and 13-20 Bq/kg in Tsivolki, Stepovogo and Abrosimova Bays respectively. These conclusions are further supported by the data for ${ }^{238} \mathrm{Pu}$ and ${ }^{239+240} \mathrm{Pu}$. Hence, leakages from the low-level waste containers on the seafloor have diminished appreciably after ten years while sediment reworking (e.g. mixing, burial, resuspension and transport) and radioactive decay has reduced to negligible the elevated radionuclide levels previously detected in surface sediments. Furthermore, there is no indication that nuclear fuel from the dumped reactors or submarine has been or is presently releasing detectable quantities of radioactivity into the marine environment.
\end{abstract}

\section{INTRODUCTION}

The White Book 3 [1] published by Russian authorities in 1993 documented the dumping of substantial quantities of solid nuclear wastes into shallow bays located along the margin of the islands of Novaya Zemlya $\left(70-80^{\circ} \mathrm{N}, 50-70^{\circ} \mathrm{E}\right)$. Nuclear reactor compartments, ships, a submarine and containers of low level radioactive waste were found at these locations although reconnaissance efforts failed to locate the nuclear icebreaker Lenin reactor compartment and packing with spent nuclear fuel, reportedly dumped in Tsivolki Bay. In 1993, ${ }^{137} \mathrm{Cs}$ contamination levels in surface sediments of Tsivolki Bay ranged from 4-30 Bq/kg, and were similar to the levels typically observed in the open Kara Sea (2-33 Bq/kg) [2-4]. Expeditions to Stepovogo (1993/94) and Abrosimova (1994) Bays revealed that sediments from seafloor locations near reactor compartments and other dumped objects did not contain appreciably elevated radionuclide concentrations. However, near-surface sediments located near leaking low level radioactive waste containers were highly-contaminated. Close to the waste containers, surface sediment ${ }^{137} \mathrm{Cs}$ levels were as high as $110,000 \mathrm{~Bq} / \mathrm{kg}$ in Stepovogo Bay and $8400 \mathrm{~Bq} / \mathrm{kg}$ in Abrosimova Bay, with traces of ${ }^{60} \mathrm{Co}$.

In addition to the 1993-1994 expeditions, a survey was conducted in 2002 for Abrosimova Bay under the auspices of the International Science and Technology Center (ISTC). Survey results [5] indicated that ${ }^{137} \mathrm{Cs},{ }^{90} \mathrm{Sr}$ and ${ }^{239+240} \mathrm{Pu}$ levels in surface bottom sediments of the major part of the Abrosimova Bay did not exceed 40, 2.5, and 1.2 Bq/kg d.w. respectively (except samples taken in close vicinity to dumped objects). A new survey, jointly organized by Russia and Norway, was conducted 
in 2003 and 2004. The survey re-assesses the artificial radionuclide contamination levels in bottom sediments in the Novaya Zemlya Bays: Tsivolki, Stepovogo and Abrosimova.

\section{MATERIALS AND METHODS}

\subsection{Sampling procedures}

Surface $(0-2 \mathrm{~cm})$ sediment samples were collected with a box-corer $\left(0.1 \mathrm{~m}^{2}\right)$ or by grab "Ocean" $\left(0.25 \mathrm{~m}^{2}\right)$ at 29 stations located in the dumping areas (Tsivolki Bay, Stepovogo Bay and Abrosimova Bay) and at two stations located in the Novaya Zemlya Trough (Figure 1). All samples were frozen onboard at $-20^{\circ} \mathrm{C}$ and stored frozen until analysis.

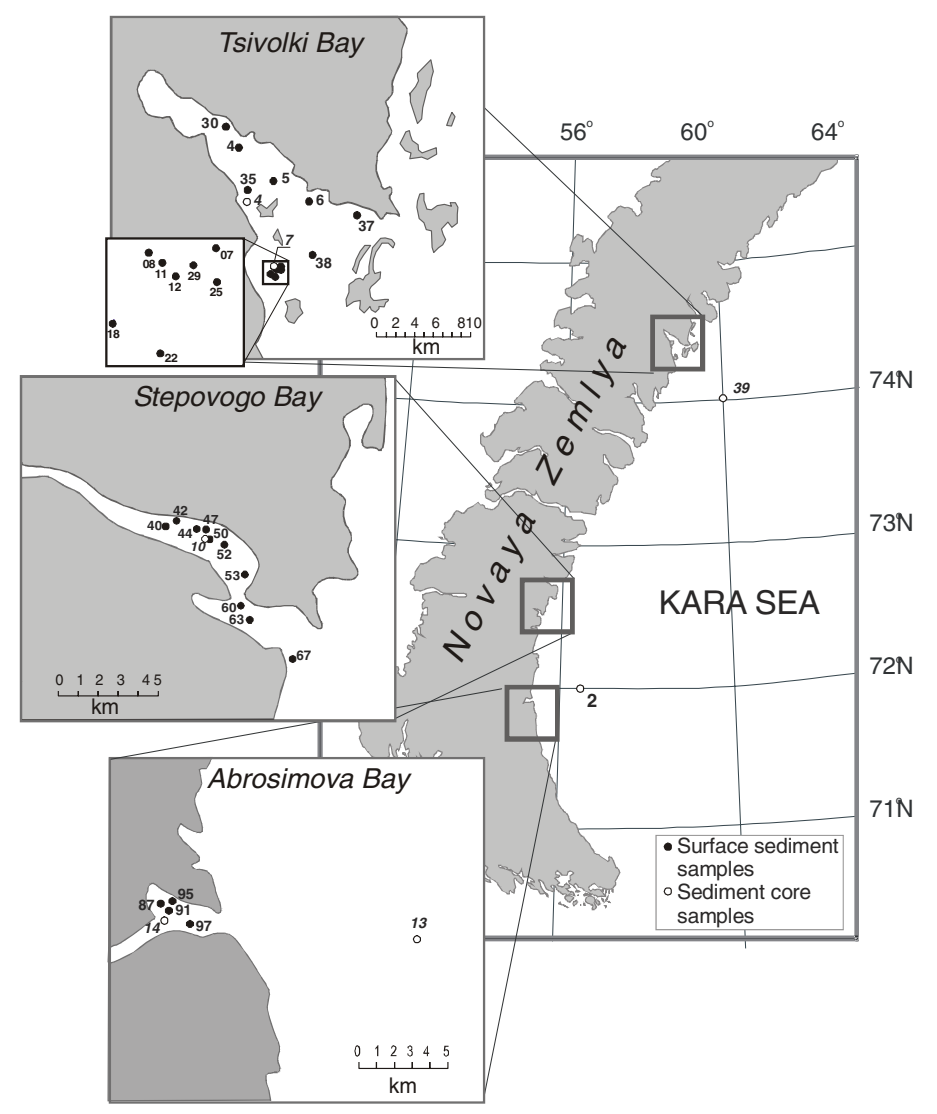

Figure 1. Sediment sampling sites, 2003-2004.

\subsection{Analysis procedures}

${ }^{137} \mathrm{Cs},{ }^{238} \mathrm{Pu}$ and ${ }^{239+240} \mathrm{Pu}$ measurements in surface bottom sediment samples were performed by SI RPA “Typhoon”.

\subsubsection{Gamma-spectrometric measurements of ${ }^{137}$ Cs specific activity}

Bottom sediment samples were dried in a desiccator with inflowing air at $70^{\circ} \mathrm{C}$. The drying samples were periodically stirred (about every $1-1.5$ hours). When drying was completed, each sample was 
homogenized. Dry and wet bottom sediment samples were weighed and packed into a container of uniform geometry for measurement by gamma-spectrometry. Sample activities were determined by a NOMAD-PLUS multichannel analyzer with ORTEC GEM-15190-S semiconductor detector (energy resolution $1.65 \mathrm{keV}$ for the $1332 \mathrm{keV}$ line). Individual samples were placed in a shielded detector to reduce the level of natural background radiation. Detector operations were monitored and controlled using the computer software GammaVision in Windows.

Sample analytical errors were minimized through sample homogenization, precise determination of sample weight, use of optimal measurement geometry, and precision placement of a sample in measurement container. In order to perform correct gamma-spectrometric analysis, the basic spectrometer characteristics were constantly controlled.

\subsubsection{Procedure for radiochemical extraction of ${ }^{238} \mathrm{Pu}$ and ${ }^{239+240} \mathrm{Pu}$}

Samples for the analysis of plutonium were concentrated using VP-1AP anionite in $\mathrm{NO}_{3}$-form from $7.5 \mathrm{~mol} / \mathrm{L}$ nitric acid with subsequent radiochemical purification on the same column. Samples were eluted from the columns with $0.01 \mathrm{~mol} / \mathrm{L}$ hydrofluoric acid in $0.35 \mathrm{~mol} / \mathrm{L}$ nitric acid. Each sample was then electro-deposited onto a stainless steel planchet. Sample quantification of ${ }^{238} \mathrm{Pu}$ and total ${ }^{239+240} \mathrm{Pu}$ was performed on an ORTEC alpha-spectrometer. ${ }^{242} \mathrm{Pu}$ was used as a tracer for the quantification of plutonium yield during radiochemical analysis.

\section{RESULTS AND CONCLUSIONS}

In this new assessment, ${ }^{137} \mathrm{Cs}$ contamination levels have diminished appreciably within both Stepovogo and Abrosimova Bays and there has been no detectable leakage from objects in Tsivolki Bay. Nearsurface sediment contamination levels in 2003/04 are 1-11 Bq/kg, 4-268 Bq/kg, and $13-20 \mathrm{~Bq} / \mathrm{kg}$ in Tsivolki, Stepovogo and Abrosimova Bays respectively. In samples from Novaya Zemlya Trough, ${ }^{137} \mathrm{Cs}$ concentration is $6.5-11 \mathrm{~Bq} / \mathrm{kg}$.

Hence, leakages from the low-level waste containers on the seafloor have diminished appreciably since 1994 while sediment reworking (e.g. mixing, burial, resuspension and transport) and radioactive decay has reduced considerably the elevated radionuclide levels previously detected in surface sediments. Furthermore, there is no indication that nuclear fuel from the dumped reactors or submarine has been or is presently releasing detectable quantities of radioactivity into the marine environment. These conclusions are further supported by the data for ${ }^{238} \mathrm{Pu}$ and ${ }^{239+240} \mathrm{Pu}$ (Table 1).

Average contamination levels of ${ }^{137} \mathrm{Cs},{ }^{238} \mathrm{Pu}$ and ${ }^{239+240} \mathrm{Pu}$ found in surface sediments from Novaya Zemlya Trough were lower than in both Stepovogo and Abrosimova Bays but higher than those found in Tsivolki Bay (Table 1).

Table 1. Activity of ${ }^{137} \mathrm{Cs},{ }^{239+240} \mathrm{Pu}$ and ${ }^{238} \mathrm{Pu}$ in surface $(0-2 \mathrm{~cm})$ bottom sediments from the eastern Novaya Zemlya bays and Novaya Zemlya Trough, 2004. Range and arithmetic mean \pm standard deviation.

\begin{tabular}{|l|c|c|c|c|}
\hline Area & $\begin{array}{c}\text { Number } \\
\text { of samples }\end{array}$ & $\begin{array}{c}{ }^{137} \mathrm{Cs}, \\
\mathrm{Bq} / \mathrm{kg} \mathrm{dw}\end{array}$ & $\begin{array}{c}{ }^{239+240} \mathrm{Pu}, \\
\mathrm{mBq} / \mathrm{kg} \mathrm{dw}\end{array}$ & $\begin{array}{c}{ }^{238} \mathrm{Pu}, \\
\mathrm{mBq} / \mathrm{kg} \mathrm{dw}\end{array}$ \\
\hline Tsivolki Bay & 15 & $1.4-11.5$ & $60-480$ & $<4.4-66.3$ \\
& & $6.2 \pm 3.5$ & $178 \pm 107$ & $10.1 \pm 15.8$ \\
\hline Stepovogo Bay & 10 & $4.4-268$ & $271-1103$ & $<7.8-354$ \\
& & $54.7 \pm 77.6$ & $619 \pm 292$ & $56.1 \pm 107$ \\
\hline Abrosimova Bay & 4 & $\begin{array}{c}13.4-21.9 \\
18.6 \pm 3.6\end{array}$ & $403-1040$ & $<18.4-112$ \\
& & $6.5-11.0$ & ${ }^{1} 439$ & $49.3 \pm 44.7$ \\
\hline NZ Trough & 3 & $9.2 \pm 2.4$ & & $<16.4$ \\
& & & \\
\hline
\end{tabular}

$$
{ }^{1} \mathrm{~N}=1 .
$$




\section{Acknowledgments}

Financial support for this work was provided by the Norwegian Radiation Protection Authority.

\section{References}

[1] White Book 3. Facts and problems related to radioactive waste disposal in seas adjacent to the territory of the Russian Federation. Office of the President of the Russian Federation, Moscow, 1993.

[2] Radioactivity in Arctic Seas. Report for the International Arctic Seas Assessment project (IASAP). International Atomic Energy Agency, Austria, 1999, 71 pp.

[3] B. Salbu, A.I., Nikitin, P. Strand, G.C. Christensen, V.B. Chumichev, B. Lind, H. Fjelldal, T.D. Bergan, A.L. Rudjord, M. Sickel, N.K. Valetova and L. Føyn., Sci. Total Environ. 202 (1997) 185-98.

[4] E.K. Duursma and J. Carroll. Environmental compartments, equilibria and assessment of processes between air, water, sediments and biota. Springer, Berlin, 1996, 277 pp.

[5] A.I., Nikitin, S.A. Lavkovsky and Y.S. Tsaturov., "Time trend of the marine environment radioactive contamination in Abrosimov Bay of the Kara Sea (according to data of field studies in 1994 and 2002)", 6 $6^{\text {th }}$ International Conference on Radioactivity in the Arctic and Antarctic, Nice, France, 2-6 October 2005, P. Strand, P. Borretzen and T. Jolle, Eds., pp. 190-193. 